\author{
NIKŠA ĆAVAR ${ }^{1}$ \\ DAMIR VULJAJ ${ }^{2}$ \\ MARIO VRAŽIĆ ${ }^{3}$ \\ ${ }^{1}$ University of Zagreb, \\ Faculty of Electrical Engineering and \\ Computing, Croatia \\ ${ }^{1}$ niksa.cavar@fer.hr \\ 2damir.vuljaj@fer.hr \\ ${ }^{3}$ mario.vrazic@fer.hr
}

\section{OVERALL EFFICIENCY IN ELECTRIC ROAD VEHICLES}

Abstract: This paper discusses the efficiency of an electric car and a conventional car. At the time when many car manufacturers are developing electric car prototypes, it is of great importance to investigate their efficiency. The paper presents an efficiency analysis of main components in an electric car. Energy consumption is obtained by performing drive cycle energy consumption simulation, which does not consider losses in the vehicle and by using declared consumption data where losses are considered. These two data sets have been used to calculate overall efficiency.

Key words: Battery, conventional car, efficiency, electric car.

\section{INTRODUCTION}

At the time of a growing demand for electric vehicles [1], their overall efficiency should be considered. From the customer's point of view, it is desirable to get as much distance traveled for the least amount of energy. Therefore, a more efficient car results in direct energy cost savings to the user. Currently, a substantial part of the market is occupied by conventional cars of low efficiency, but there is a growing tendency of regulatory agencies to decrease $\mathrm{CO}_{2}$ emission what brings electric cars into focus. This paper discusses the overall efficiency of electric cars since it is usually desirable to have components with highest possible efficiency for the long term.

According to the EPA test procedure, conventional vehicle consumption is declared in miles per gallon (MPG), whereas electric vehicle consumption is declared in miles per gallon equivalent (MPGe). The consumption is measured in laboratory conditions and it includes a mix of different tests. In [2] the whole measurement process is described in detail. The declared consumption considers electric energy taken from the electric outlet and energy of petrol stored in the reservoir.

Main disadvantages of electric vehicles are insufficient range and unavailability of charger network. In [3], [4] authors suggest methods for range extension which would make an electric car competitive with a conventional car.

The efficiency of a car can be calculated by taking into consideration cumulative effect of each component efficiency [5] but also it can be calculated by considering a consumption obtained from the simulation of the ideal vehicle model and a declared consumption.

\section{EFFICIENCY ANALYSIS}

\section{Electric car efficiency analysis}

Electric car analysis starts from the place where a customer pays for the electrical energy. According to Figure 1, it is an electric outlet. Electrical energy flows from the public grid to the charger, then to the battery pack and from the battery pack to the drive and to the auxiliary system.

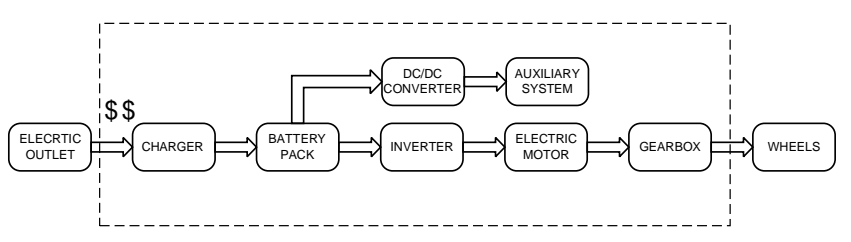

Figure 1. Energy flow in an electric car.

Total losses $P_{\text {loss }}$ can be calculated as follows:

$P_{\text {loss }}=P_{\text {loss }, \text { ch }}+P_{\text {loss }, \text { bat }}+P_{\text {loss }, \text { inv }}+P_{\text {loss }, \text { mot }}+$

$+P_{\text {loss }, g b x}+P_{\text {loss }, \text { conv }}+P_{\text {aux }}$.

The total efficiency $\eta_{\text {tot. }}$ of the system is:

$\eta_{\text {tot. }}=\frac{P_{\text {wheels }}}{P_{\text {wheels }}+P_{\text {loss }}}$

The auxiliary system consumption is in this case considered as loss.

\section{Charger}

SAE 2011 standard defines three levels of AC and DC charging stations. Each level presents a power level for charging [6]. AC charging stations supply power to On - board chargers, which consists of a rectifier and DCDC converter, while DC charging stations use Off board chargers, meaning that they directly supply the battery with DC power.

According to [7], the efficiency of the new generation charger in Chevrolet Bolt electric car reaches $93 \%$ at lower voltage and $95 \%$ at higher voltage. Advanced 
chargers can reach more than 94\% efficiency [8]. This data is approved in [9].

\section{Battery pack}

A battery pack in an electric car provides energy for the vehicle movement. The efficiency of the battery pack can be calculated as the ratio of the energy available for discharging and the energy used to charge the battery pack. Losses in the battery pack are caused by ohmic losses due to the internal resistance of the battery. Consequently, higher charging or discharging current leads to higher losses and lower efficiency.

Virtanen et al. in [10] claim an efficiency of more than $90 \%$ for $30 \mathrm{LiFePO} 4$ cells connected in series, whereas at lower current the efficiency is approximately $94 \%$. Zhang et al. in [11] also approved those results. Likewise, in [11] it is shown that lower current leads to higher efficiency. Vitols in [12] showed that an efficiency of the passively balanced battery pack is roughly $94 \%$, however the author used charge and discharge current of $0.25 \mathrm{C}$ which leads to lower losses.

\section{Inverter}

The inverter is used to efficiently control the electric motor. When DC voltage is applied to the input there is a sinusoidal voltage of arbitrary frequency on the output. Heat dissipation in an inverter is caused by switching and conducting losses. Switching losses are increased by increasing the switching frequency and conducting losses are increased by increasing the current.

According to Oak Ridge National Laboratory analysis, peak inverter efficiency is about $97 \%$ but the efficiency at lower speed is $80 \%-90 \%$ [13]. By using advanced switches (SiC) efficiency can be increased to $98 \%$ [14].

\section{Electric motor}

The maximum speed of an electric motor in electric vehicles is usually greater than $10000 \mathrm{rpm}$ to achieve high power to weight ratio. That is why a single speed gearbox is used. Motor peak efficiency can reach $97 \%$ in peak efficiency operating point. However, a car is moving through a large set of operating points and make a calculation of overall efficiency hard to perform. An efficiency map is a possible solution but proprietary manufacturer data is hard or almost impossible to find.

Losses in the electric motor are divided into three groups:

- Copper losses

- Iron losses

- Mechanical losses

Copper losses incur due to current flow through the conductor, iron losses arise from eddy current losses and hysteresis losses while mechanical losses are caused by friction and ventilation. The motor efficiency can be enhanced by using materials with lower specific losses.
By analyzing data from car manufacturers, it is determined that peak efficiencies of electric motors are between $95 \%$ and $97 \%{ }^{1}$.

\section{Gearbox}

Electric cars usually have gearboxes with only one gear. A special feature of the electric motor is the ability to use full rated torque even for speed near $0 \mathrm{rpm}$. It is an advantage compared to internal combustion engines which need few transmission levels. By using only one transmission level, the complexity is decreased while the overall efficiency is increased.

Electric car manufacturer Rimac Automobili claims that the efficiency of single speed gearbox is greater than 97\% while two-speed gearbox efficiency is greater than 95\%. Moreover, manufacturer BorgWarner Inc. also states that the efficiency of single speed gearbox is $97 \%$.

\section{DC - DC converter}

A DC-DC converter in an electric car is used to supply auxiliary systems (lights, infotainment system, electronic systems etc.). It uses energy from the main battery pack. Moreover, an auxiliary deep cycle lead battery is used to power loads when the car is turned off.

In [15] peak efficiency of the converter is roughly $96 \%$. A DC-DC converter in [16] reaches slightly higher efficiency. Zhong Nie et al. in [17] suggest a converter with the efficiency of $82 \%-92 \%$ for the power in the range $10 \%-100 \%$ of the rated power.

By using peak efficiency data from the analysis the total calculated efficiency of an electric car is $78 \%$.

\section{Conventional car efficiency analysis}

Conventional car analysis starts from the petrol station. The energy chain includes a reservoir, internal combustion engine, gearbox, alternator and auxiliary system as it is depicted in

Figure 2.

According to [18] the efficiency of internal combustion engine is between $28 \%$ and $32 \%$. Likewise, the same source claims that the overall efficiency of the conventional car is between $14 \%$ and $30 \%$. On the other hand, an author in [19] claims that the efficiency of conventional motors is less than $20 \%$.

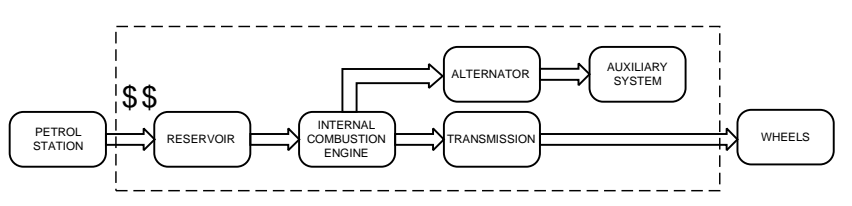

Figure 2. Energy flow in a conventional car.

From the mentioned numbers for conventional vehicles and those obtained from electric car analysis for one

\footnotetext{
${ }^{1}$ Data is retrieved from the following manufacturers: Rimac Automobili, General Motors Company and Nissan Motor Corporation
} 
operating point, it is clear that electric car is more efficient.

\section{VEHICLE CONSUMPTION SIMULATION}

US Environmental Protection Agency (EPA) defines speed profile for urban (Figure 3) and highway driving (

Figure 4).

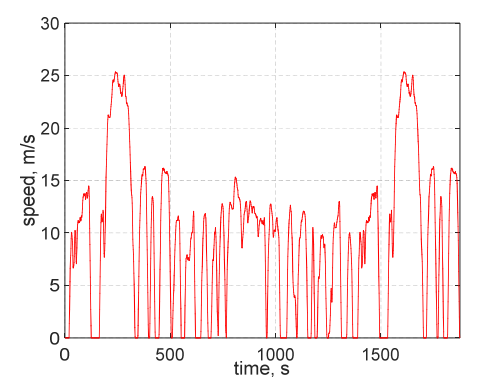

Figure 3. EPA urban driving cycle (FTP)

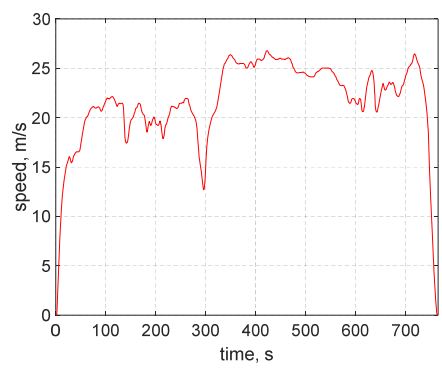

Figure 4. EPA highway driving cycle (HWFET)

Performed tests characteristics are given in Table.

Table 1. Performed test characteristics

\begin{tabular}{lll}
\hline Test & Urban & Highway \\
\hline Maximum speed, m/s & 25.35 & 26.82 \\
\hline Average speed, m/s & 9.48 & 18.02 \\
\hline Distance, $\mathrm{km}$ & 17.77 & 16.51 \\
\hline Duration, s & 1874 & 765 \\
\hline
\end{tabular}

EPA test procedure for testing highway and city driving uses a 5 cycle method which includes various cycles (FTP75, FTP20, US06, SC03 and HWFET). Each cycle represents a specific operating scenario for the vehicle:

- FTP20 represents a city cycle at ambient temperature of $-6.7^{\circ} \mathrm{C}$

- FTP75 represents a city cycle at ambient temperature of $23.9^{\circ} \mathrm{C}$

- HWFET represents highway cycle
- US06 represents a drive cycle with high speed and acceleration

- SC03 represents a city cycle with air condition load.

The fuel economy rating is given by combining those 5 cycles. The actual ratio of individual samples for calculating the fuel economy is different for each vehicle.

The fuel economy rating is measured using emission and consumption test of a wide variety of cycles. It is also necessary to note that simulation of a 5-cycle test is very complicated and impractical because a temperature model of ICE and EV drivetrain should be used for FTP20 and FTP75 tests, as well as cold start consumption estimation and vehicle $\mathrm{A} / \mathrm{C}$ consumption should be known. That is why MPG based estimation of 5 cycle test from 2 cycle test is used. The expression used for 2 cycle to 5 cycle fuel economy conversion in urban driving cycle is [2]:

$$
F E_{5 C \_c i t y}=\frac{1}{0.003259+\frac{1.18053}{F E_{F T P}}}
$$

and for highway driving cycle is [2]:

$$
F E_{5 C \_ \text {highway }}=\frac{1}{0.001376+\frac{1.3466}{F E_{H W F E T}}}
$$

where $F E$ represents fuel economy measured in miles per gallon (MPG).

The main idea for calculating vehicle efficiency is to simulate fuel consumption for an ideal powertrain with vehicle drag parameters and compare the results with actual EPA fuel economy data.

This article presents energy consumption simulation of a conventional car manufactured by Mercedes - Benz as well as an electric car manufactured by Tesla Motors. Car parameters used in the simulation are shown in Table. It is important to note that a mass of the driver is added to the mass of a vehicle.

The simulation is used to determine energy consumption of vehicles. Losses of vehicle components are neglected in the simulation.

Table2. Car parameters used in the simulation.

\begin{tabular}{lll}
\hline & $\begin{array}{l}\text { Mercedes } \\
\text { CLA250 }\end{array}$ & $\begin{array}{l}\text { Tesla Model } \\
\mathrm{S}\end{array}$ \\
\hline Mass, $\mathrm{kg}$ & $1485+75$ & $2000+75$ \\
\hline $\mathrm{c}_{\mathrm{rr}}{ }^{2}$ & $9.6 \cdot 10^{-3}$ & $7.15 \cdot 10^{-3}$ \\
\hline $\mathrm{c}_{\mathrm{d}}{ }^{3}$ & 0.3 & 0.24 \\
\hline $\begin{array}{l}\text { Frontal area, } \\
\mathrm{m}^{2}\end{array}$ & 2.167 & 2.399 \\
\hline Drag area, $\mathrm{m}^{2}$ & 0.650 & 0.576 \\
\hline
\end{tabular}

\footnotetext{
2 rolling resistance coefficient

${ }^{3}$ drag coefficient
} 
Distance traveled is calculated according to the following expression:

$s=\int v \cdot d t$

and speed is obtained from the given speed curve which is defined by EPA.

Totally consumed energy for the given speed curve is calculated in the following manner:

$E=\int P_{\text {tot }} \cdot d t$,

where $P_{\text {tot. }}$ represents a total power of the vehicle during constant speed operation or acceleration.

The total power is consumed on:

- Rolling resistance losses

- Air resistance losses

- Vehicle acceleration

Rolling resistance coefficients are obtained from the declared energy class for tires used in Tesla Model $S$ and Mercedes CLA250. Rolling resistance coefficients for different energy classes are given in [20].

After the calculation of total consumed energy in $\mathrm{kWh}$, it is necessary to calculate the energy in gallons according to the following expression derived from EPA:

$E_{\text {gallon }}=\frac{E_{k W h}}{33.7}$.

Afterwards, that data is used to calculate the efficiency of the electric car:

$\eta=\frac{F E_{\text {declared }}}{F E_{\text {sim. }}} \cdot 100 \%$.

\section{RESULTS}

According to presented data in Table, it can be noted that the electric car consumes less energy than the conventional car. If efficiencies of these two cars are compared the electric car is approximately 2.5 times more efficient. From that point of view, the electric car is a better choice for the consumer.

By comparing simulation results for two cars one can note that the conventional car does not provide a possibility to return energy back in the system like an electric car. There is an area in Figure 7 and Figure 8 where consumed energy decreases due to regenerative braking. For the conventional car, the flat area only exists which means that energy is neither consumed nor returned in the car.

Table 3. Results obtained from the simulation.

\begin{tabular}{lllll}
\hline & \multicolumn{2}{l}{ Mercedes CLA250 } & \multicolumn{2}{c}{ Tesla Model S } \\
\cline { 2 - 5 } & Urban & $\begin{array}{l}\text { Highwa } \\
\text { y }\end{array}$ & Urban & $\begin{array}{l}\text { Highwa } \\
\text { y }\end{array}$ \\
\hline Energy $^{4}$ & 2.17 & 1.80 & 1.15 & 1.49 \\
\hline 5C CC & 98.72 & 119.41 & 144.45 & 139.47 \\
\hline
\end{tabular}

\footnotetext{
4 in $\mathrm{kWh}$
}

\begin{tabular}{lllll}
\hline $5 \mathrm{C} \mathrm{DC}^{6}$ & 26.0 & 37.0 & 97.0 & 100.0 \\
\hline $\begin{array}{l}\text { Efficienc } \\
\mathrm{y}\end{array}$ & $26.3 \%$ & $31.0 \%$ & $67.2 \%$ & $71.7 \%$ \\
\hline
\end{tabular}

Conventional cars are able to run auxiliary systems and $\mathrm{A} / \mathrm{C}$ with regenerative energy.

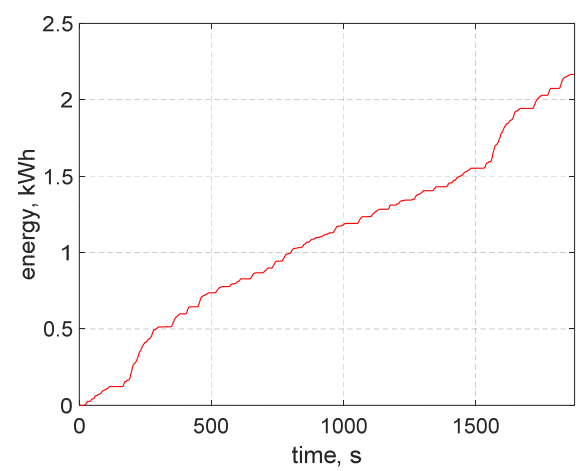

Figure 5. Energy consumption of Mercedes CLA250 in urban driving cycle.

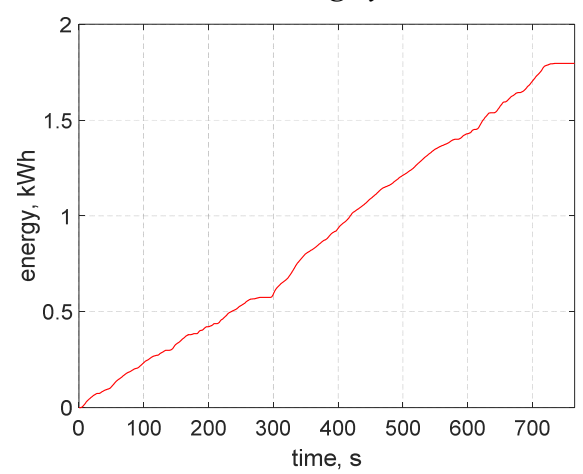

Figure 6. Energy consumption of Mercedes CLA250 in highway driving cycle.

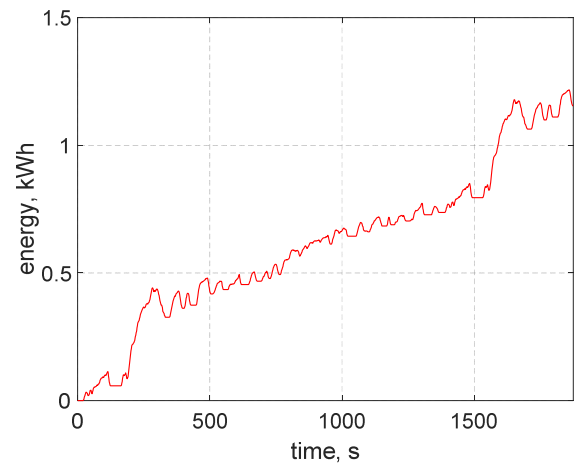

Figure 7. Energy consumption of Tesla Model S in urban cycle. 


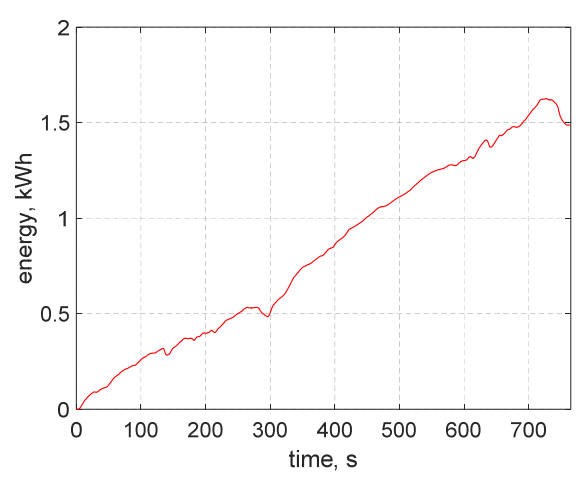

Figure 8. Energy consumption of Tesla Model $S$ in highway driving cycle.

\section{CONCLUSION}

This paper presents a comparison between a conventional car and an electric car efficiency. By separating an electric car in components and by analyzing each component individually, it has been determined that each component in the chain has an efficiency greater than $80 \%$ but overall efficiency of the vehicle is roughly $70 \%$. Results obtained for the conventional vehicle suggest that it is approximately 2.5 times less efficient that an electric car. Data provided in the analysis are based on peak efficiency but a vehicle moves through many operating points, thus a component efficiency is constantly changing. The future work should focus on direct measurement of components efficiency as well as a development of methods that will correctly assess their overall efficiency.

\section{REFERENCES}

[1] K.B. Naceur: "Global EV Outlook 2017 two million and counting", IEA Publications, 2017.

[2] Environmental Protection Agency, "Final technical support document: Fuel economy labeling of motor vehicle revisions to improve calculation of fuel economy estimates", Epa420-R-06-017, 2006.

[3] S.D. Pinto, Q. Lu, P. Camocardi, C. Chatzikomis, A. Sorniotti, D. Ragonese, G. Iuzzolino, P. Perlo, C. Lekakou, "Electric vehicle driving range extension using photovoltaic panels," In Proc. IEEE Vehicle power and propulsion conference (VPPC), 2016.

[4] P. Dost, P. Spichartz, C. Sourkounis: "Examination of potential for range extension in electric vehicles based on fleet measurements", In Proc. IEEE Vehicle power and propulsion conference (VPPC), 2014.

[5] M. Murray: "Total system efficiency," Power transmission engineering, 2010, pp. 16-23.

[6] SAE Hybrid Committee, "SAE charging configurations and ratings terminology", 2011. [Online]. Available: http://www.sae.org/smartgrid/chargingspeeds.pdf.

[7] D. Cesiel, C. Zhu: "A closer look at the on-board charger: The development of the second-generation module for the Chevrolet Volt", IEEE Electrification magazine, Vol. 5, No. 1, 2017, pp. 36-42.

[8] K. Stengert: "On-board $22 \mathrm{~kW}$ fast charger "NLG6"”, World Electric Vehicle Symposium and Exhibition (EVS27), 2013.
[9] H. Bai, W. Guo, G. Szatmari-Voicu, N. Wang, J. Patterson, J. Kane, A. Taylor: "Design of an $11 \mathrm{~kW}$ power factor correction and $10 \mathrm{~kW}$ ZVS DC/DC converter for a high-efficiency battery charger in electric vehicles", IET Power electronics, Vol. 5, No. 9, 2012, pp. 1714-1722.

[10] A. Virtanen, H. Haapala, S. Hannikainen, T. Muhonen, H. Tuusa: "Calorimetric efficiency measurements of supercapacitors and lithium-ion batteries", In Proc. Twenty -sixth annual IEEE applied power electronics conference and exposition (APEC), 2011.

[11] P. Zhang, C. Du, F. Yan, J. Kang: "Influence of practical complications on energy efficiency of the vehicles lithium-ion batteries", In Proc. International conference on electric information and control engineering, 2011.

[12] K. Vitols: "Efficiency of LiFePO4 battery and charger with passive balancing", In Proc. IEEE 3rd Workshop on advances in information, electronic and electrical engineering (AIEEE), 2015.

[13] R. Staunton, T. Burress, L. Marlino: "Evaluation of 2005 Honda Accord hybrid electric drive system", 2006.

[14] K. Kumar, M. Bertoluzzo, G. Buja: "Impact of SiC MOSFET traction inverters on compact-class electric car range", In Proc. IEEE International conference on power electronics, drives and energy systems (PEDES), 2014.

[15] A. Kumar, P. Gaur: "Bidirectional DC/DC converter for hybrid electric vehicle", In Proc. International conference on advances in computing, communications and informatics (ICACCI), 2014.

[16] S. Hu, C. Mi, M. Zhang, J. Deng: "Optimal design of line level control resonant converters in plug-in hybrid electric vehicle battery chargers", IET Electrical systems in transportation, Vol. 4, No. 1, 2014, pp. 2128.

[17] Z. Nie, W.D. Williams, C. Duan, W. Guo, K.H. Bai: "System optimization of a high-power and high-stepdown accessory power module for electric vehicles", IEEE Applied power electronics conference and exposition (APEC), 2014.

[18] J. Thomas: "Drive Cycle Powertrain Efficiencies and Trends Derived from EPA Vehicle Dynamometer Results", SAE International journal of passenger cars mechanical systems, Vol. 7, No. 4, 2014, pp. 13741384.

[19] US Department of Energy: "Hydrogen fuel cells", 2006. [Online]. Available: https://www.hydrogen.energy.gov/pdfs/ doe_fuelcell_factsheet.pdf.

[20] J.M. Acedo, "Review study on the Regulation (EC) No $1222 / 2009$ on the labelling of tyres", 2016. 


\section{BIOGRAPHY}

Nikša Ćavar was born in Dubrovnik, Croatia, in 1992.

He received B.Sc. and M.Sc. degrees in Electrical Engineering from the University of Zagreb, Croatia in 2014 and 2016 respectively. Currently, he is a Research Associate

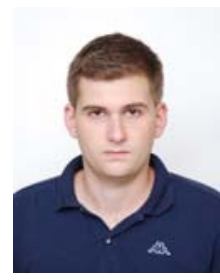
at the University of Zagreb, Faculty of Electrical Engineering and Computing, Department of Electric Machines, Drives and Automation, Croatia where he is working toward the Ph.D. degree. His research interests include design, modeling, analysis, and optimization of electric machines.

\section{UKUPNA EFIKASNOST ELEKTRIČNIH VOZILA}

Nikša Ćavar, Damir Vuljaj, Mario Vražić

Rezime: Tema ovog rada je efikasnost električnog i konvencionalnog automobila. U današnje vreme kada većina proizvođača automobila razvija prototipove električnih automobila, od velikog je značaja ispitati njihovu efikasnost. U radu je analizirana efikasnost glavnih komponenata električnog automobila. Potrošnja energije se izračunava uz pomoć simulacije potrošnje energije u ciklusu vožnje gde u obzir nisu uzeti gubici u vozilu, kao i uz pomoć tačno definisanih podataka o potrošnji sa gubicima. Ova dva skupa podataka su iskorišćena za izračunavanje ukupne efikasnosti.

Ključne reči: akumulator, konvencionalni automobil, efikasnost, električni automobil. 